Sanda Lucija Udier

UDK 811.163.42'243'367.626.6

Faculty of Humanities and Social Sciences

University of Zagreb

Croatia

sludier@ffzg.hr
DOI: $10.4312 /$ vestnik.13.427-444

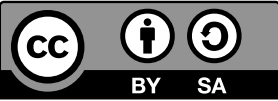

\title{
PRAGMATIC CHARACTERISTICS OF INDEFINITE PRONOUNS IN CROATIAN AS A SECOND LANGUAGE
}

\section{PRAGMATIC COMPETENCE AND ITS IMPORTANCE IN TEACHING CROATIAN AS A SECOND LANGUAGE}

Communicative competence consists of linguistic, sociolinguistic and pragmatic competence (Vijeće Europe 2005: 13), and pragmatic competence includes competence in discourse, competence in planning, and functional competence (Nazalević Čučević 2015: 41). In Croatian as a second language (CL2) the speaker at the B2 level starts the conversation, successfully converses back and forth and concludes the conversation. When describing and recounting the conversation, he makes use of examples and details by connecting his statements into clear and consistent discourse by various cohesive means. A command of pragmatic competence at the B2 level is manifested in the possibility of formulating what is to be said in various ways and in the adaptation of the theme, style and tone to match the communication setting (Nazalević Čučević 2015: 52). At the B2 level, the ways to express opinions and viewpoints are diverse, structurally complex and communicatively functional. In order for all this to be possible, it is necessary, in addition to the denotative, to master the connotative level of meaning of lexical units, i.e. the level of meaning that is often implicit, invisible, difficult to grasp and difficult to explain, and which greatly affects communication. In teaching CL2, one can often hear students recount an experience where "a word did not mean what it means" in a communicative situation. For example, if a person comments on something with the IP pronoun: "Svašta!" with an exclamatory intonation, it may refer to the primary meaning of that pronoun ('a set of various unnamed objects 1 '), or it can also entail a negative attitude towards something that happened. Students of CL2, and probably of other languages, find it difficult to master this level of language use, although it becomes necessary at higher levels of language competence (from B2 upwards), because unfamiliarity with it can make communication difficult and, ultimately, lead the speaker into an awkward situation, like any other unawareness of socio-linguistic conventions.

1 Source: rječnik.hr http://xn--rjenik-k2a.hr/search/?q=sva\%C5\%A1ta accessed November 29, 2020. 
Precisely because of the need to include such linguistic usages in teaching, i.e. because of the need to make it easier for students to master the pragmatic function in another language, intercultural pragmalinguistics has been developed (Kecskés 2014, 2015), which has the task of analysing the pragmatic level of language in an intercultural context, and the results of the research conducted under the auspices of intercultural pragmatics have been successfully applied in the teaching of other languages.

\section{$2 \quad$ LINGUISTIC DESCRIPTION OF INDEFINITE PRONOUNS}

In both international and Croatian linguistics, indefinite pronouns (IP) have been covered relatively little in comparison with other types of words.

\subsection{Indefinite Pronouns in World Linguistics}

The formal and semantic features of IP in international linguistics were most systematically addressed by Martin Haspelmath, who published a comparative study of IP with examples from 40 languages (Haspelmath 1997). In his study, the emphasis is on the relationship between the formal and functional characteristics of IP. IP typically appear in sequences that refer to ontological categories (person, thing, place, time, manner, etc.), and so, for example, English has sequences with the following components: some-, no-, every- and any-. Russian has sequences with these components: -to, -nibud' and -libo, koe-, ni-, ljuboj- etc. It turned out that very different languages have a similar typology of IP, and the differences in meaning and function that IP can express proved interesting. The analysis shows that seemingly equivalent IP in different languages cannot be used in exactly the same contexts, so it is necessary to make a comparison between languages in order to determine where each of them is used, i.e. to see which pronouns in which language cover which of the listed categories (Haspelmath 1997: 76). IP are mostly derived from interrogative pronouns by adding indefinite markers. Indefinite markers are usually particles which come either as prefixes or as suffixes, and they almost never participate in inflection. Often interrogative pronouns can also be used as IP. Related languages show a very different distribution of IP (Haspelmath 1997: 293). Languages differ not only by the forms of their IP, but also by their number and the functions they express. Therefore, the comparison of IP in different languages is fruitful. The semantics and pragmatics of IP synchronically and diachronically were covered by Guevara, Aloni, Port and Šimik (2011) by analysing them according to Haspelmath's functions, and IP expressing free choice were analysed in particular (Guilar-Gueveara, Aloni, Port, Schulz and Šimik 2010), where it was concluded that different IP are actually the result of the fossilization of different pragmatic effects. This supports the claim that the pragmatic function is essential when it comes to IP. 


\subsection{Indefinite Pronouns in Croatian Linguistics}

Just like in international linguistics, IP are covered very little in Croatian linguistics, and apart from Croatian grammars (Silić and Pranjković 2005, Barić et al. 1997, Raguž 1997), only Lučić (2005) has written about them. Grammars mostly focus on their formation in their descriptions, and a description of meaning is given only by Raguž (1997: 70-72). Apart from Lučić (2005), there is no other research on the meaning and pragmatic characteristics of IP, and thus none on the possibility of expressing a negative attitude by using IP. Expressing a negative attitude with IP belongs to the colloquial register of language, and colloquial language is otherwise poorly researched in Croatian linguistics.

\subsubsection{The Formation of Indefinite Pronouns}

According to E. Barić et al. (1997: 206-207), IP are identical to interrogative and relative pronouns, and more of them are formed by prefixation, or the addition of one of the following prefixes, particles or words: ne-, ni-, i-, sva-, koje-, po-, pone-, gdje-, što- and -god-. The prefixes $s v a-, n i-, i-, s_{t} t o-, k o j e-$ are usually followed by the form $-s$ sta, and rarely or never by the form -što, while the other prefixes go with -što. Expressions composed of the interrogative or relative pronoun together with certain words or forms are used as IP, some of which are placed only in front of the pronoun, others only behind the pronoun, while others may stand either behind or in front of the pronoun. Ma, makar, bud and budi go before the pronoun, while the particle bilo comes either before or after the pronoun. The words god, mu drago, ti volja, te volja, hoćes and hoće are placed after the pronoun. The numeral jedan can also function as an IP with a meaning corresponding to neki, netko, isti, nitko or nikakav, and the ordinal numeral drugi can as well when contrasted with demonstrative pronouns and the adjectives ostali and ini.

Silić and Pranjković (2005: 127ff) state that IP appear in simple and complex forms. The simple forms are tko, što, čiji, koji and kakav, while the complex forms are those with the prefixes ne-, ni-, i-, sav-, koji-, kakav- and the pronominal suffixes -tko, -što, -čiji, -koji, -kakav and -kolik. IP can also be (1) prefixes: tko-, što-, čiji-, koji-, kakav-, kolikand the suffix -god, (2) with the particle ma and the pronouns tko, što, čiji, koji, kakav and kolik, (3) with the particle bilo and the pronouns tko, što, čiji, koji, kakav and kolik as well as (4) with the pronouns tko, što, čiji, koji, kakav, kolik and the particle god, mu drago and god mu drago.

\subsubsection{The Morphology of Indefinite Pronouns}

When it comes to declension, in IP only the forms tko, što, čiji, koji, kakav and kolik are declined, both as independent forms and in combination with prefixes and suffixes (Silić i Pranjković 2005: 128). Out of all the IP, only the pronoun kolik has both an indefinite and definite declension. When prepositions are used with the pronouns nitko, ništa, ničiji, 
nikoji, nikakav and nikolik as well as itko, išta, ičiji, ikoji, ikakav and ikolik, they are placed between the prepositions $n i$ - and $i$ - and the pronoun. Prepositions are also placed between the prefixes (particles) $m a$ and bilo and the pronouns tko, što, čiji, koji, kakav and kolik. Therefore, in declension, the prefixes $i$ - and $n i$ - behave as separate words, and so they come before the preposition (ičim, ničim, is čim, ni s čim, i u čemu, ni u с̌еmu). Other pronoun prefixes are never separated in that manner (Raguž 1997: 70-72). In declension, pronouns functioning as prefixes in compound sentences are not declined (koješta, koječega, koječemu).

Based on the linguistic description of IP in the Croatian language (CL), it can be concluded that they form a very complex derivational and morphological system. Corpus linguistic research should be used to examine how much of this system is really active in the language production of native speakers of the CL, and that part should be taught in the instruction of CL2. In second language teaching, the language that its native speakers produce on a daily basis should be taught, while other segments can be taught as needed (Udier and Gulešić Machata 2011a: 349).

\subsubsection{Syntax of Indefinite Pronouns}

The use of IP in sentences was analysed by Silić and Pranjković (2005: 132-133), and they concluded: (1) the pronouns tko, što, čiji, koji and kakav are used only in compound sentences (Naiđete li na kakav trag, obavijestite nas. 'If you come across any clues, let us know.') and in those sentences they can be replaced with the pronouns netko, nešto, nečiji, nekoji and nekakav, and tkogod, štogod, čijigod, kojigod i kakavgod. (2) The pronouns nitko, ništa, ničiji, nikoji, nikakav and nijedan can be used either in simple or compound sentences which must be negative, and they cannot be replaced by any other IP. (3) The pronouns itko, išta, ičiji, ikoji, ikakav, ikolik and ijedan are used in interrogative, colloquial and affirmative sentences, and they can replace the pronouns bilo tko, bilo što, bilo čiji, bilo koji, bilo kakav and bilo kolik (Ako itko o tome može išta znati, to je on. 'If anyone knows anything about it, it's him.'). (4) The pronouns bilo tko... can be used in both simple and compound sentences. And (5) the pronouns ma tko, ma što, ma čiji, ma koji and ma kakav can be used in both concessive and conditional sentences (Zadovoljit će me ma kakav odgovor. 'Any answer will satisfy me.'), and they can replace the pronouns tko god... kakav god... čiji god..., and others.

D. Raguž (1997: 70-72) lists pronouns in different types of hypothetical sentences: (1) interrogative (Poznaješ li ijednoga? 'Do you know any of them?'); (2) conditional (Ako ikoga vidiš, prenesi poruku. 'If you see anyone, pass the message on.'); (3) comparative (Bilo je ljepše nego ikada. 'It was nicer than ever.'); (4) declarative (Ne vjerujem ikomu. 'I don't trust anyone.'); and (5) relative (Čovjek koji išta zna ne bi to napravio. 'A man who knows anything would not do that.'). Hypothetical sentences also use an IP (interrogative-relative) without any prefix (Je li tko dolazio? 'Did anyone come?', Daj mi 
koju. 'Give me some.', Ako te tko pita, reci da ne znaš. 'If anyone asks you, say you don't know.', Ma što odabrao, dobro je. 'Whatever you choose, it's good.'). It could be argued whether IP with the prefix $i$ - are indeed in explicit sentences, and whether they are attested in the modern CL. This claim should also be verified by corpus linguistic research.

Radovan Lučić conducted an analysis of IP with constituents bilo and god based on the possible positions they occupy in the sentence (Lučić 2005). He showed that the position of these IP in a sentence depends on their meaning. IP beginning with the prefixes $s v a$ - can be in the starting position, but they cannot be in the initial position for pronouns in $i$-. When bilo means $i$-, it cannot stand in the initial position (Bilo tko čini grijeh, čini $i$ bezakonje. 'Whoever commits sin also commits lawlessness.'), but when it means sva-, then it can (Bilo što da zatreba, ja sam ovdje. 'Whatever he needs, I am here.'). In such use, the conjunction $d a$ is added. When it comes to the final position, it is "reserved" for pronouns with the component bilo which has the meaning 'whichever', and can have both ironic and pejorative meanings (Govore kako pravo na grb ima bilo tko. 'They say that anyone has the right to a coat of arms.'). In colloquial language, it is not uncommon to use pronouns with the component god as well (On priča što god! 'He says whatever.'). Lučić also showed the syntagmatic limitations of the use of the particles bilo and god as parts of IP: the conjunctions ako, makar and nego can stand in front of compound pronouns with bilo, but not in front of complex pronouns with god (Lučić 2005: 443).

\subsubsection{The Meaning of Indefinite Pronouns}

There are very few texts examining the meaning of IP in the CL, and corpus-linguistic research on this topic does not currently exist. Grammars of the CL tend to deal less with the meaning of IP and more with their formation and syntax. Baric et al. stated that each of these prefixes that participate in the formation of IP, in addition to the meaning of indefiniteness, also add additional connotations to the meaning of IP: (a) ne- gives the meaning of uncertainty when something is not known or is something one does not want to say; (b) $n i$ - gives the meaning of negation and is used in negative sentences in contrast with $n e$ - in the affirmative; (c) $i$ - introduces a permissive meaning and entails existence in its lowest quantities, measures or values and is therefore the opposite of $n i-$; (d) $s v a$ means wholeness or comprehensiveness; (e) gdje- means occasionalness, sporadicness, scattering in time and space, a meaning the prefix po-also has when alongside pronouns beginning with the prefix ne-; (f) što- and koje- mean diversity of kind and quality, often not the best; and (g) god-means non-selection, indeterminacy and indifference to choice (1997: 206-207). It is said, therefore, that the prefixes što- and koje-can have a pejorative meaning, but this is not elaborated on in more detail.

Silić and Pranjković only state in principle that IP are used alongside indefinite objects, beings, traits, concepts and phenomena. Nevertheless, they concretise this assertion by listing the particles god, ma (makar) and bilo (mu, vam) drago which, along with the 
meaning of emphasis, also have the additional connotation of giving permission (2005: 127ff). They come with relational words, and the combination of relativity and concession results in a habitual meaning (Silić and Pranjković 2005: 254), i.e. the meaning of repeating something. Thus, the relative pronoun becomes the indefinite koji god $=$ svaki = bilo kakav = svakakav (Tko god dođe, neka je dobro došao. 'Whoever comes, let him be welcome.'). Pragmatics is not mentioned by these authors.

D. Raguž states that the number of pronoun words increases by adding prefixes as modifiers of meaning, and these modifiers are shared amongst pronouns and adverbs (1997: 70-72). Modifiers only come with a basic IP. The prefix ne- does not indicate negation, but rather indefiniteness, while the prefix $n i$ - means negation (completely), while the prefix $i$-gives the pronouns a permissive and hypothetical meaning to the smallest, and not just any, degree. The prefix $s v a$ - has the meaning of comprehensiveness, and the prefix $p o-$ appears before the prefix $n e$ - and gives the meaning of random selection or distributivity. The prefixes koje- and što- add a concessive connotation to the quality and choice, thus permitting even the worst quality and choice (and so these words often have a derogatory meaning). The prefix koje- is associated with all pronoun words, and even with pronominal adverbs, while the prefix gdje- has a limited number and limited quality of meanings.

The following can come as independent modifiers or suffixes in IP: (1) the suffix -god which has the meaning of hypothetical indefiniteness (kakogod, kogagod), and (2) the independent modifier god (always after the pronoun) which has a concessive meaning with pronouns (Koga god da pitaš, reći će ti to isto. 'Whoever you ask will tell you the same thing.'). The following modifiers are separate: ma, makar, bilo mu (ti, vam...) drago - they have a concessive meaning. Bilo can come before or after the pronominal word (tko bilo, bilo tko), as well as either before or after a preposition (s bilo kim, bilo s kim). Syntagmata with $m u$ (joj, vam...) drago come only after the pronominal word (komu $t i$ drago). Makar and ma come only before the pronominal word (makar što, ma što). These modifiers (bilo, što mu drago) can be found in independent sentences as well (Može učiniti što mu je drago. 'He can do what he pleases.'). The modifiers ma, makar and god are more rarely found in independent sentences, especially in the colloquial language (Može makar što. 'Sure, anything.').

In the article Kaj god! R. Lučić (2005) deals with the intensifiers bilo and god and with their influence on the meaning and syntax of the complex IP in whose formation they play a part. The function of the intensifiers god and bilo is to extend the concessive meaning to indefiniteness, arbitrariness, and unlimited possibility of choices. They can have an ironic and pejorative meaning (Govore kako pravo na grb ima bilo tko. 'They say that anyone has the right to a coat of arms.'). According to Lučić (2005: 340) the pronouns itko and išta mean the existence of at least one being or object of least value, quality or measure. The pronouns netko and nešto have the meaning of an indefinite person, an unknown object or phenomenon, they can mean that the noun is not known or not 
wanted to be pronounced, and it can also have the meaning of uncertainty. The pronouns svatko and sve mean completeness, comprehensiveness regardless of quality and number, and indifference to choice.

We can conclude that Croatian grammars (Barić et al. 1997, Silić and Pranjković 2005) generally do not provide information on pragmatics, so they do not answer the question of how the usable context contributes to the meaning of IP. Valuable data on the pragmatic value of IP are provided by Lučić (2005: 342) and Raguž (1997: 70-72), and their conclusions can be considered the beginning of the research on the pragmatic properties of IP in the CL that needs to be conducted.

\section{INDEFINITE PRONOUNS IN THE CONTEXT OF TEACHING} CROATIAN AS A SECOND LANGUAGE

Because some of them (netko, nešto, sve, svašta, nitko, ništa...) are among the most commonly used words in the CL, IP are taught right from the start when learning CL2, most often through a lexical approach (Bergovec 2007), while structured teaching is conducted from the B2 level onwards (Čilaš Mikulić, Gulešić Machata and Udier 2015: 88-89, Udier and Gulešić Machata 2017: 194-196). The formation, syntax and morphology of the compound IP deriving from the pronouns tko, što, čiji, koji, kakav and kolik in combination with the prefixes $n e-, i-, n i$ - and $s v a$ - are taught systematically, while the IP with the prefixes koje-, gdje-, with the suffix -god and with the particles ma and bilo are only mentioned with a note that they belong to a higher variety of the Croatian standard language and are predominantly found in the written language.

However, there are very few occurrences found in the corpus for part of the IP system that is taught, and that shows a discrepancy between the system and usage, which leads to the question of which forms and uses should be taught - all those that are in the system or those that are closer to the actual usage, i.e. the conclusion that in teaching one should pay attention to the sometimes asymmetrical relationship between the system and usage, where preference should be given to usage (Udier and Gulešić Machata 2011a: 340, Udier and Gulešić Machata 2011b: 68). It follows from all of the above that IP are a major challenge for CL2 language instructors given their complex semantics, morphology and syntax.

4

THE PRAGMATIC POTENTIAL OF INDEFINITE PRONOUNS IN THE CROATIAN LANGUAGE

The pragmatic properties of pronouns in general, and consequently of IP, have not yet been dealt with in more detail in Croatian linguistics. The reason is probably the fact that 
it is difficult to analyse the meaning of pronouns because it is always highly dependent on the context and the meaning of the word they replace. Kuna (2007) noticed the pragmalinguistic potential of IP, writing about pronominalization as one of the ways of forming euphemisms. Pronominalization refers to the alternation of a content word (i.e. the autosemantic word) with a pronoun that acquires lexical meaning in a speech situation or linguistic context (Kuna 2007: 105). In his examples he cites demonstrative pronouns (vidjeti onu stvar 'to see that thing - to see one's sexual organ', raditi one stvari 'to do those things - to have sexual relations') and the reflexive-possessive pronoun (imati svoje dane 'to have one's days - to menstruate'), and of the IP he mentions only nešto and sve (učiniti nešto za njega 'to do something for someone - to do something illegal for someone' and bilo je tu svega 'here there was everything - a lot of unpleasant things happened').

Other linguists have also noticed the pragmalinguistic potential of IP (Raguž 1997: 70-72 and Lučić 2005: 340) in expressing implicit negative attitudes, and their potential for such use is also revealed by some humorous non-scientific texts, for example the entry for Makaršta on the online dictionary: Ausvajs bite ${ }^{2}$. The pragmalinguistic potential of IP as a challenge in acquiring CL2 was also a motivator in conducting this research.

By researching the command of pragmatic properties of IP among CL2 students ${ }^{3}$, specifically in using them to express implicit negative attitudes, an answer was sought to the question to what extent CL2 students at the B2 and C1 levels of language competence have acquired a command of the meaning of IP and their use in expressing a negative attitude.

2 Makaršta-A word which universally negates value. It is a favourite of grandparents when they want to express a focused critique of an entity in its entirety, but also in detail, from 1969 onwards. And not only that, this word also describes extraordinarily well any and all aspirations, dreams, hopes, efforts and intimate and social values of young people now and onwards. Examples: Ma, on studira nešto neke kompjutere, ma makaršta. "He studies something with computers or whatever.", Internet? Makaršta! "Internet? Whatever that is!", Ta njegova ženskica.... Makaršta. "That little lady of his...whatever", Deda, vidi, fotografije s Marsa! Deda: Makaršta... "Grampa, look, photographs from Mars! Grampa: Whatever." It is perhaps interesting to examine the thought demon which this word lets run amok. This word is a linguistic perpetual motion machine in a vicious cycle of creation and destruction of existence. As a particle it is permanently locked on to the "event horizon". Makaršta constantly indicates the possibility of the existence of some value (makar-) and subsequently demolishes and destroys it with the question word-šta, as if it didn't even exist. So, if we were to seek out the antithesis of the notion of existence and being, we would easily agree that "the non-existent" or "what is not" describes one such concept relatively well, relative to "what is". That is, we would easily agree with such a dichotomy only if we are not familiar with "makaršta" - because this word is not a soft and stale concept of non-being, not at all! This word shares nothing with anything you know, it stands between being and non-being and kills God in both. Example: Sendvič!? Šta jedeš to makaršta! (A sandwich!? Why are you eating that rubbish!) https://leksikon.thinking-garment.com/makarsta/ (Accessed November 9, 2020)

3 The term CL2 student is used as a generic term and means "person who learns Croatian as a second language" regardless of that person's age and in what way and in what context they learn CL2. 


\subsection{Research Hypotheses}

The research question is concretized by the following hypotheses:

H1: CL2 students at levels B2.1, B2.2 and C1 have mastered the meaning of IP.

H2: CL2 students at levels B2.1, B2.2 and C1 are not as well versed in the pragmatic nature of IP (the ability to express a negative attitude) as in their meaning.

H3: With the increase of the language competence of CL2 students, the mastery of the pragmatic properties of IP (the ability to express a negative attitude) also increases.

H4: CL2 students at levels B2.1, B2.2 and C1 whose first language is one of the Slavic languages have a better command of the pragmatic dimension of IP than students whose first language is not Slavic.

H5: CL2 students at levels B2.1, B2.2 and C1 are less proficient in the pragmatic dimension of IP in production than in comprehension.

\subsection{Sample in Research}

The research was conducted on a suitable sample of 60 CL2 students who attended semester classes at Croaticum in the 2019/2020 academic year. There were 20 participants in the study at the lower level of B2 (B2.1), 22 at the higher level of B2 (B2.2), and 18 at the level of $\mathrm{C} 1$. The first languages of the respondents expressed in percentages are: Polish: 22\%, Spanish: 15\%, English: 10\%, German: 8\%, Bulgarian: 8\%, Italian: 5\%, Hungarian: $5 \%$, others: $27 \%$. The total number of speakers of Slavic languages was $39 \%$, and non-Slavic was $61 \%$.

\subsection{Ethical Assumptions of Research}

The study Ovladanost pragmatičkim svojstvima neodređenih zamjenica u hrvatskome kao inom jeziku ('The Command of the Pragmatic Properties of IP in Croatian as a Second Language') was approved by the Ethics Committee for Scientific Research at the Faculty of Humanities and Social Sciences, University of Zagreb by a decision on September 10th, 2019. Respondents signed an informed consent form and were familiar with the purpose of the survey and how to conduct it. It was explained to them that the results of the research would be calculated in bulk and that their personal data would be kept strictly confidential, i.e. available only to the researcher.

\subsection{Research Method and Research Instrument}

The research was conducted by the quantitative method, and the research instrument was a questionnaire intended to determine to what extent CL2 students know the meaning 
of IP and how much they recognise the attitude expressed by them. The questionnaire consisted of two parts that the respondents answered separately so that the part in which they had to indicate the IP would not affect the part in which they are not explicitly mentioned. The parts were later linked together using a code that the respondents typed in independently.

In the first part of the questionnaire the respondents had to complete six sentences with words that corresponded in meaning. The sentences were taken from the hrWaC 2.0 corpus (Ljubešić and Erjavec 2011),with the IP that was originally in them omitted, and words that matched the meaning had to be filled in (with an unlimited number of possible options). The purpose was to see how many of the words entered would be IP. The sentences used were: Hodala bih pognute glave jer bi vojnici na prozorima dobacivali (...) Većina takvih radnika je nakon osnovne škole išla na (...) tečajeve upitne obrazovne vrijednosti. Vidiš, postoje (...) ljudi, oni koji traže osvetu ili jednostavno žele nekome nanijeti zlo. Zadnjih par dana Maja nije dobro spavala i budila se po noći tako da je bila sva (...) Nastavi li se situacija u državi kotrljati nizbrdo, bit će (...) iza Nove godine. Lako je predvidjeti reakciju normalnog čovjeka, ali od budale možě̌ (...) očekivati.

The second part of the questionnaire consisted of 12 test items that checked the respondents' command of the meaning of IP and the recognition of the negative or neutral meanings that they had (here they are listed in the case forms in which they appeared in the questionnaire): koješta, kojekakve, svakakve, nikakva, svašta, koječemu, nikakav, sve, svašta, kojekakvim, svakakvi and svega). Thus, knowledge of the meaning of each IP was checked on two test items, in one of which the pronoun had a basic meaning (that is, a specific type of indefiniteness), and in the other where it implicitly expressed a negative attitude. Examples were chosen in which it was not obvious from the context of the sentence what its pragmatic function was. For example sentences like Ljudi su poslije toga postali ludi i vjeruju u koješta. ('People went crazy after that and believe in whatever.') were not included, because from of the adjective "ludi" (crazy) it could easily be concluded that the attitude towards what the IP refers to is negative. Examples were chosen so that they did not contain vulgar words, political views or politically incorrect expressions that could offend someone. Efforts were made to choose short and simple sentences so that the respondents' attention would not be diverted. Sentences used in the questionnaire were: Mi bismo vam u Splitu o tome mogli koješta reći. Treba kupiti i okititi božićno drvce i još kojekakve druge sitnice. Imao sam diplomu u džepu i morao sam raditi svakakve poslove. Mačići su posve ovisni o majčinu mlijeku i ne treba im nikakva druga hrana. O njoj se danas piše svašta. Pričali smo o koječemu, sve onako bez reda. To je za mene prije svega nikakav čovjek. Perfekcionisti sve uspiju napraviti dobro. Naravno da možete još svašta iskombinirati u ovom receptu. Cilj je udruge da se suprotstavi kojekakvim nevladinim udrugama. Danas na tržištu postoje svakakvi modeli, od šarenih $i$ veselih do onih vrlo sofisticiranih i modernih. Kad sam vidio tko sudi, znao sam da će biti svega. 
Since there is no firm criterion by which it could be established with certainty that an IP expresses a negative or neutral attitude in a certain context, three independent evaluators were hired, all CL2 experts (M. Čilaš Mikulić, M. Gulešić Machata and D. Matovac), and the questionnaire included sentences which all assessors agreed expressed an appropriate attitude (negative or neutral, depending on the test item).

\subsection{Results of the Research}

The results of the research, which relate to knowledge of the meaning of the IP koješta, kojekakav, svakakav, nikakav, sve and svašta, as well as to the recognition of the negative or neutral attitudes they express, are shown in Table 1. The results show that a very high percentage of CL2 students at the B2 and C1 levels of language competence mastered the meaning of all IP which were studied (mastery is an acquisition ranging between $80 \%$ and $88 \%$ ), while their recognition of neutral and, particularly, the negative attitude expressed by IP was much weaker (on average $52.8 \%$ ). They showed a particularly poor recognition of a negative attitude expressed by the pronouns koješta and kojekakav (21\% and $30 \%$, respectively).

Table 1. Knowledge of the meaning of the IP koješta, kojekakav, svakakav, nikakav, sve and svašta and recognition of the attitudes which they express

\begin{tabular}{|l|c|c|c|}
\hline $\begin{array}{l}\text { Indefinite } \\
\text { pronoun }\end{array}$ & $\begin{array}{c}\text { Knowledge } \\
\text { of meaning }\end{array}$ & $\begin{array}{c}\text { Recognition } \\
\text { of a neutral attitude }\end{array}$ & $\begin{array}{c}\text { Recognition } \\
\text { of a negative attitude }\end{array}$ \\
\hline koješta & $80 \%$ & $58 \%$ & $21 \%$ \\
\hline kojekakav & $81 \%$ & $75 \%$ & $30 \%$ \\
\hline svakakav & $85 \%$ & $54 \%$ & $63 \%$ \\
\hline nikakav & $88 \%$ & $61 \%$ & $73 \%$ \\
\hline sve & $86 \%$ & $59 \%$ & $66 \%$ \\
\hline svašta & $86 \%$ & $49 \%$ & $64 \%$ \\
\hline
\end{tabular}

When it comes to the results obtained from the analysis of the second part of the questionnaire in which the respondents had to write in words that match according to their meaning, and which express a negative attitude (Table 2), respondents at the B2.1 level wrote an average of 5.70 words, of which 0.95 or $16.67 \%$ were IP, respondents at the B2.2 level wrote an average of 6.14 words, of which 1.00 word were IP (16.29\%), while respondents at the $\mathrm{C} 1$ level entered an average of 8.50 words, of which 1.50 words were IP (17.65\%). 
Table 2. Proportion of IP among words that match in meaning and context (expression of a negative attitude) according to levels of language competence

\begin{tabular}{|l|c|c|c|}
\hline $\begin{array}{l}\text { Level of } \\
\text { language competence }\end{array}$ & B2.1 & B2.2 & C1 \\
\hline $\begin{array}{l}\text { Proportion of } \\
\text { indefinite pronouns }\end{array}$ & $16.29 \%$ & $16.67 \%$ & $17.65 \%$ \\
\hline
\end{tabular}

When comparing the results achieved by the respondents who are native speakers of one of the Slavic languages with the results of the respondents who are speakers of non-Slavic languages (Table 3), it can be seen that the speakers of Slavic languages wrote an average of 6.96 words, of which 1.22 (17.53\%) were IP, while non-Slavic native-speakers wrote an average of 6.56 words, of which $1.08(16.46 \%)$ were IP.

Table 3. Proportion of IP among words that match in meaning and context (expression of a negative attitude) according to type of first language

\begin{tabular}{|l|c|}
\hline Type of first language & Production of indefinite pronouns \\
\hline Slavic first languages & $17.53 \%$ \\
\hline Non-Slavic first languages & $16.46 \%$ \\
\hline
\end{tabular}

6

\section{DISCUSSION}

The first hypothesis, that CL2 students at the B2.1, B2.2 and C1 levels have acquired a command of the meaning of IP, is confirmed. This was to be expected given the fact that the structure of the CL is already completely acquired by the B2 level (Udier 2015: 249), but this hypothesis had to be confirmed by the research because a command of the meaning is a prerequisite for acquiring a command of the pragmatic features.

The second hypothesis, that CL2 students at the B2.1, B2.2 and C1 levels have a weaker command of the pragmatic property of IP (the possibility of expressing a negative attitude) in comparison with their meaning, is confirmed only in part, i.e. it is confirmed only in the IP koješta and kojekakav, while it is not confirmed for the pronouns svakakav, nikakav, sve and svašta. This difference in acquisition can be partly explained by the frequency of pronouns (the pronoun koješta in the hrWaC corpus has 4,789 tokens, and the pronoun kojekakav has 18,467, while the pronoun svakakav has 18,731 tokens, nikakav 331,572 tokens, sve 786,886 tokens and svašta 55,313 tokens ${ }^{4}$ ), especially for the pronoun koješta, which is significantly less represented in the hrWaC corpus than other IP

4 All data about the number of tokens is taken from the hrWaC corpus at the following link: https://www.clarin.si/ noske/all.cgi/first_form?corpname=hrwac;align $=($ accessed December 2, 2020) 
(with only 4,789 tokens). Greater acquisition can be attributed to some extent to a higher frequency in the language which, since it is a sign of greater repetition and use, leads to more effective cognitive implantation (Langacker 1988, 2000). However, frequency alone cannot explain the fact that the respondents acquired a command of the pragmatic function of the pronouns kojekakav (18,467 tokens, acquisition of 30\%) and svakakav $(18,731$ tokens, acquisition of $63 \%)$, which are very close, in terms of representation, in the corpus. The reasons for the uneven acquisition of pronouns of similar frequency should be sought elsewhere, most likely in the way students were taught the pronouns, which cannot be investigated in this study.

That the increase in the language competence of CL2 students also increases their command of the pragmatic properties of IP (the ability to express a negative attitude), which was claimed in the third hypothesis, was also confirmed. Although explicit instruction of the pragmatic properties of IP is not contained within the CL2 textbooks that have been analysed (Čilaš Mikulić, Gulešić Machata and Udier 2015, Udier and Gulešić Machata 2017, Korom 2005), CL2 speakers at high levels of language proficiency still acquire it. The percentages that show the representation of IP among the words that they correspond to by context are not large (ranging from $16.29 \%$ to $17.65 \%$ ), and the increase in the use of IP in the appropriate context is proportional to the level of language competence (B2.1 16.29\%, B2.2 16.67\% and C1 17.65\%), although it is not large (the difference between the level of $\mathrm{B} 2.1$ and $\mathrm{C} 1$ is only $1.36 \%$ ). This fact leads to the conclusion that there is still room for improvement in teaching, and it can be assumed that systematic and explicit teaching of the pragmatic properties of IP would result in greater and pragmatically more appropriate usage. This hypothesis should be tested by further research preceding the development of a model for teaching IP that would include their pragmatic properties.

The hypothesis that CL2 students at the B2.1, B2.2 and C1 levels whose first language is one of the Slavic languages better master the pragmatic dimension of IP than students whose first language is not Slavic was also confirmed, but with very small difference in values - the representation of IP in Slavic speakers was $17.53 \%$, and in non-Slavic ones $16.46 \%$, so the difference is only $1.07 \%$. The results show that CL2 students who speak related Slavic languages generally have a slightly richer vocabulary with a slightly higher share of IP compared to CL2 students of non-Slavic origin, on the basis of which it can be assumed that there was a positive transfer from the other Slavic languages into Croatian. However, caution should be exercised when relying on positive transmission from related languages, because analyses have shown that related languages can have significantly different IP systems (Haspelmath 1997: 293), and that seemingly equivalent IP in different languages, even related ones, cannot be used in all the same contexts. It would be useful to conduct a comparative analysis of the meaning and pragmatic potential of IP in different Slavic languages, as well as other languages, in order to illustrate and explain similarities and differences in relation to Croatian, and 
to determine in which contexts and meanings seemingly equivalent IP are used or not (Haspelmath 1997: 293).

From the results of this research, specifically from the small difference in the production from Slavic and non-Slavic respondents (only 1.07\%), it follows that the difference between Slavic speakers and non-Slavic speakers learning CL2 is not so large as to require a different approach when teaching. The research also confirmed the fifth hypothesis that CL2 students at the B2.1, B2.2 and C1 levels are less proficient in the pragmatic dimension of IP in production than they are in comprehension.

Some of the results of this research were expected - respondents at higher levels of language competence in CL2 listed more words which match in meaning in comparison with students from lower levels of language competence. The amount of IP with a certain pragmatic function used appropriately increases with the amount of words, and CL2 students whose first language is one of the Slavic languages have a slightly richer vocabulary and use slightly more IP.

However, the second part of the results of this research was less expected and shows that the proportion of IP in all words used by respondents is relatively small (between $16.67 \%$ and $17.65 \%$ ), which leads to the conclusion that respondents use relatively few IP that match the meaning in a particular context, that is, that their recognition of a pragmatic function predominates over its production in specific communication settings. Although it is universally known that among learners of a second language comprehension is dominant over production (they are much more able to understand when they listen or read than they are able to say or write), still, the proportion of IP in production is very minor and points to the fact that with awareness of them and better teaching things could be improved, which would allow CL2 students to better realise the specific pragmatic function of IP that was discussed in this research (that of expressing a negative attitude).

The research also opened many other questions, for example the question of how much of the complex system of IP is actually used in everyday communication in the CL, since CL2 teaching also has the purpose of teaching only that which is actually used. Frequency analysis would show us which IP have a higher frequency in the CL, and these pronouns should then be taught chronologically earlier and quantitatively to a greater degree. But out of everything, the most important factor regarding the teaching of CL2 in lessons would be an exhaustive linguistic description of the pragmatic function of those IP that are actively and often used in the CL in order to base their explicit teaching on that description. It would also be necessary to explore the meanings and feelings expressed by IP in idiomatic expressions such as: nitko $i$ ništa ('nobody and nothing, a person with no value'), sve i svašta ('anything and everything'), svakakav ('all sorts, a euphemism for something bad'), onakav ('not much of a person/thing'), etc., because their understanding is necessary for quality communication in the $\mathrm{CL}$ at higher levels of language competence. 
The results of the research show that the pragmatic level needs to be included more frequently and more thoroughly in the teaching of CL2 because its mastery is an essential component of language competence, especially at higher levels. The results of the research indicate the conclusion that - in addition to everything else already taught - the pragmatic properties of IP should also be taught, and additionally idiomatic expressions with IP should be learned lexically (for example ima nas svakakvih 'there are all kinds of us', on je nitko i ništa 'he is nobody and nothing', svakakva osoba 'shady person').

The teaching of IP in CL2 should be based on the results of corpus research on representation and frequency, on research on the acquisition of the system of IP and, first and foremost, on a scientific description of the meaning of IP that includes the pragmatic level. It is necessary to not only teach from an explicitly grammatical approach, but also to teach lexically in such a way that includes the pragmatic level, because IP (as well as other types of pronouns) have great pragmatic potential.

In the future, it will be necessary to make a more complete linguistic description of the pragmatics of IP that could then be applied in CL2 teaching, as well as to make a better general description of the pragmatic level of the CL, which is still relatively undescribed, and whose description will be a great challenge for experts given the fact that this level cannot be described by formal linguistic instruments.

\section{REFERENCES}

AGUILAR-GUEVARA, Ana/Maria ALONI/Angelika PORT/Katrin SCHULZ/Šimik RADEK (2010) Free choice items as fossils. Workshop on Indefiniteness Crosslinguistically (DGfS) Berlin, February 25-26, part one and part two. https://www. semanticscholar.org/paper/Free-choice-items-as-fossils-Guevara-Aloni/e8c16bfdb621ff49a03ffb0fe4af03320fc80527\#paper-header (Accessed March 2, 2021)

AGUILAR-GUEVARA, Ana/Maria ALONI/Angelika PORT/Šimik RADEK (2011) Semantics and Pragmatics of Indefinites: Methodology for a Synchronic and Diachronic Corpus Study. Proceedings of the Workshop Beyond Semantics: corpus-based Investigations of Pragmatica and Discourse Phenomena, 1-16. Goettingen, Germany, 23-25 February 2011, Bochumer Lingvistische Areitsberichte (3) https://www. academia.edu/9963031/2011._Semantics_and_pragmatics_of_indefinites_methodology_for_a_synchronic_and_diachronic_corpus_study._In_Proceedings_of_ the_workshop_Beyond_Semantics_--_Corpus-based_investigations_of_pragmatic_and_discourse_phenomena._Bochum_Bochumer_Linguistische_Arbeiten (Accessed March 2, 2021) 
BARIĆ, Eugenija et al. ${ }^{2}(1997)$ Hrvatska gramatika. Zagreb: Školska knjiga.

BERGOVEC, Marina (2007) Leksički pristup nastavi stranih jezika s posebnim osvrtom na hrvatski. Lahor: časopis za hrvatski kao materinski, drugi i strani, vol 1, br. 3 , 53-66.

BRALA VUKANOVIĆ, Marija/Mihaela MATEŠIĆ (2015) Croatian 'pointing words': Where body, cognition, language, context and culture meet. Branimir Belaj (ed.) Dimenzije značenja, Zbornik Zagrebačke slavističke škole. 31-62.

ČILAŠ MIKULIĆ, Marica/Milvia GULEŠIĆ MACHATA/Sanda Lucija UDIER (2015) Razgovarajte s nama! Udžbenik hrvatskoga kao drugoga i stranoga jezika za razinu B2. Zagreb: FF press.

HASPEMATH, Martin (1997) Indefinite pronouns. Oxford: Oxford University Press. KECSKÉS, Istvan (2014) Intercultural Pragmatics. Oxford: Oxford University Press. KECSKÉS, Istvan (2015) Intracultural Communication and Intercultural Communication: Are They Different? International review of pragmatics 7 (2015), 171-194.

KOROM, Marija (2005) Kroatisch für die Mittlestufe: Lese- und Übungstexte. München: Otto Sagner Verlag.

KUNA, Branko (2007) Identifikacija eufemizama i njihova tvorba u hrvatskom jeziku. Fluminensia 19, 1, 95-113.

LANGACKER, Ronald W. (1988) A usage-based model. Brygida Rudzka-Ostyn (ed.) Topics in Cognitive Linguistics. Amsterdam, Philadelphia: John Benjamins, $127-164$.

LANGACKER, Ronald W. (2000) A Dynamic Usage-Based Model. Michael Barlow, Suzanne Kemmer (ed.) Usage-Based Models of Language, Stanford: CSLI Publications, 1-64.

LJUBEŠIĆ, Nikola/Tomaž ERJAVEC (2011) 'hrWaC and slWaC: Compiling Web Corpora for Croatian and Slovene'. In TSD'11: Proceedings of the 14th international conference on Text, Speech and Dialogue, Ivan Habernal and Václav Matoušek (ed.) 395-402. Berlin, Heidelberg: Springer.

LUČIĆ, Radovan (2005) Kaj god! Jagoda Granić (ed.) Semantika prirodnog jezika i metajezik semantike, zbornik Hrvatskoga društva za primijenjenu lingvistiku, Zagreb i Split: HDPL, 437-445.

NAZALEVIĆ ČUČEVIĆ, Iva (2015) Pragmalingvistična kompetencija na razini B2. Milvia Gulešić Machata and Ana Grgić (ed.) Hrvatski B2, Opisni okvir referentne razine B2 u hrvatskom jeziku, Zagreb: FF press, 41-54.

RAGUŽ, Dragutin (1997) Praktična hrvatska gramatika. Zagreb: Medicinska knjiga.

SILIĆ, Josip/Ivo PRANJKOVIĆ (2005) Gramatika hrvatskoga jezika za gimnazije i visoka učilišta. Zagreb: Školska knjiga.

UDIER, Sanda Lucija/Milvia GULEŠIĆ MACHATA (2011a) Kakvom jeziku poučavati neizvorne govornike? Viši i niži varijetet u poučavanju hrvatskoga kao inog jezika. Nova Croatica, V, 5, 329-349. 
UDIER, Sanda Lucija/Milvia GULEŠIĆ MACHATA (2011b) Registri i hrvatski kao ini jezik. Pavel Krejčí, Elena Krejčová and Michal Przybylski (ed.) Výuka jihoslovanských jazyků v dnešní Evropě, Porta Balkanica, 64-71.

UDIER, Sanda Lucija (2015) Gramatička kopetencija. Milvia Gulešić Machata and Ana Grgić (ed.) (2015) Hrvatski B2: Opisni okvir referentne razine B2. 247-272.

UDIER, Sanda Lucija/Milvia GULEŠIĆ MACHATA (2017) Razgovarajte s nama! Gramatika $i$ pravopis hrvatskoga jezika s vježbama za razine B2-C1, drugo izdanje. Zagreb: FF press.

VIJEĆE EUROPE (2005) Zajednički europski referentni okvir za jezike. Zagreb: Školska knjiga i Vijeće Europe.

POVZETEK

\section{PRAGMATIČNE ZNAČILNOSTI NEDOLOČNIH ZAIMKOV V HRVAŠČINI KOT DRU- GEM JEZIKU}

Prispevek obravnava nekatere pragmatične značilnosti hrvaških nedoločnih zaimkov, zlasti možnost njihove rabe za izražanje negativnega odnosa oziroma stališča. V prispevku predstavljamo rezultate kvantitativne raziskave, katere namen je bil ugotoviti, v kolikšni meri učenci hrvaščine kot drugega jezika obvladajo rabo nedoločnih zaimkov za izražanje negativnega odnosa. V vprašalniku, ki je bil sestavljen iz dveh vsebinskih sklopov, smo preučevali raven razumevanja in dejanskega izkoriščanja pragmatičnih danosti hrvaških nedoločnih zaimkov. V vprašalnik smo vključili primere, ki smo jih pridobili iz korpusa hrvaških spletnih besedil hrWaC 2.0 (Ljubešić in Erjavec 2011). Raziskavo smo izvedli med učenci hrvaščine kot drugega jezika, ki so se v študijskem letu 2019/20 udeležili jezikovnih tečajev Centra za hrvaščino kot drugi in tuji jezik Croaticum na Univerzi v Zagrebu. Raven znanja hrvaščine anketirancev je ustrezala stopnjama B2 in C1 Skupnega evropskega referenčnega okvira $(\mathrm{N}=60)$. Rezultate naše raziskave bo mogoče s pridom uporabiti pri razvijanju učnih gradiv, namenjenih obravnavi semantičnih in pragmatičnih lastnosti nedoločnih zaimkov pri pouku hrvaščine kot drugega jezika. Raziskava je pokazala, da se je pri pouku hrvaščine kot drugega jezika $v$ prihodnje treba bolj posvetiti obravnavi pragmatičnih vidikov rabe nedoločnih zaimkov, saj je ravno obvladovanje pragmatične ravni jezika zlasti pri govorcih na višji jezikovni stopnji eden ključnih pokazateljev jezikovnih kompetenc. Poleg pragmatičnih lastnosti nedoločnih zaimkov bi bilo treba pri pouku obravnavati tudi idiomatične izraze, $v$ katerih se pojavljajo nedoločni zaimki. Zaradi številnih pragmatičnih danosti teh zaimkov je nujno, da jih pri pouku ne obravnavamo le s strogo slovničnega, temveč tudi z leksikalnega vidika, ki omogoča ustrezno obravnavo pragmatične ravni jezika.

Ključne besede: nedoločni zaimki, hrvaščina kot drugi jezik, pragmatične strukture, izražanje negativnega odnosa 


\section{ABSTRACT \\ PRAGMATIC CHARACTERISTICS OF INDEFINITE PRONOUNS IN CROATIAN AS A SECOND LANGUAGE}

This paper deals with some of the pragmatic characteristics of indefinite pronouns, specifically about the potential for expressing a negative attitude or stance by using them. The results of a quantitative survey will be presented exploring to what extent the potential to express a negative attitude using indefinite pronouns has been mastered. The research questionnaire consisted of two parts and examined the respondents' command in terms of both comprehension and production of the pragmatic properties of indefinite pronouns in Croatian as a second language (CL2), and the examples used in the questionnaire were taken from the hrWaC 2.0 corpus (Ljubešić and Erjavec 2011). The research was conducted among students of CL2 at the levels B2 and C1 (N=60) who attended the programs of Croaticum - Centre for Croatian as Foreign and Second Language, University of Zagreb in the 2019/2020 academic year. The results obtained in this research can be applied in the development of learning materials intended for teaching the semantic and pragmatic features of indefinite pronouns in the instruction of CL2. They show that the pragmatic level needs to be included more thoroughly in the teaching of CL2 because its mastery is an essential component of language competence, especially at higher levels. The pragmatic properties of IP should also be taught, as should idiomatic expressions with IP. It is necessary to not only teach from an explicitly grammatical approach, but also to teach lexically in such a way that includes the pragmatic level, because IP have great pragmatic potential.

Keywords: indefinite pronouns, Croatian as a second language, pragmatic structures, expressing a negative attitude 